\title{
Soluble Production, Characterization, and Structural Aesthetics of an Industrially Important Thermostable $\beta$-Glucosidase from Clostridium thermocellum in Escherichia coli
}

\author{
Syed Shoaib Ahmed (D), Mohsina Akhter, ${ }^{2}$ Muhammad Sajjad, ${ }^{1,3}$ Roquyya Gul $\left(\mathbb{D},{ }^{1,4}\right.$ \\ and Sana Khurshid ${ }^{1}$ \\ ${ }^{1}$ Institute of Molecular Biology and Biotechnology, Centre for Research in Molecular Medicine, The University of Lahore, \\ Bhobatian Chowk, 1-Km Defence Road, Lahore 54500, Pakistan \\ ${ }^{2}$ School of Biological Sciences, Quaid-e-Azam Campus, University of the Punjab, Opp. Sheikh Zaid Hospital, Canal Bank Road, \\ Lahore 54590, Pakistan \\ ${ }^{3}$ Department of Life Sciences, University of Management and Technology, Johar Town, Lahore 54000, Pakistan \\ ${ }^{4}$ Faculty of Life Sciences, Gulab Devi Educational Complex, Ferozpur Road, Lahore 54000, Pakistan \\ Correspondence should be addressed to Roquyya Gul; roquyya.gul@gdec.edu.pk
}

Received 5 August 2019; Revised 16 September 2019; Accepted 1 October 2019; Published 7 November 2019

Academic Editor: Yun-Peng Chao

Copyright (c) 2019 Syed Shoaib Ahmed et al. This is an open access article distributed under the Creative Commons Attribution License, which permits unrestricted use, distribution, and reproduction in any medium, provided the original work is properly cited.

\begin{abstract}
This study aims to achieve high-level soluble expression and characterization of a thermostable industrially important enzyme, i.e., beta-glucosidase (BglA; EC: 3.2.1.21), from Clostridium thermocellum (C. thermocellum) by cloning in an Escherichia coli (E. coli) expression system. BglA was expressed as a partially soluble component of total cellular protein (TCP) having a molecular weight of $\sim 53 \mathrm{kDa}$ with $50 \%$ of it as soluble fraction. Purification in two steps, namely, heat inactivation and Ni-chromatography, yielded approximately $30 \%$ and $15 \%$ of BglA, respectively. The purified ( 98\%) BglA enzyme showed promising activity against the salicin substrate having a $K_{\mathrm{m}}$ of $19.83 \mathrm{mM}$ and a $V_{\max }$ of $0.12 \mu \mathrm{mol} / \mathrm{min}$. The enzyme had an optimal temperature and $\mathrm{pH}$ of $50^{\circ} \mathrm{C}$ and 7.0 , respectively, while retaining its catalytic activity up till $60^{\circ} \mathrm{C}$ and at $\mathrm{pH}$ 7. The optimized maximum expression level was attained in M9NG medium with lactose as an inducer. Circular dichroism revealed presence of alpha helix (43.50\%) and small percentage of beta sheets $(10.60 \%)$. Factors like high-end cellulolytic activity, fair thermal stability, stability against low $\mathrm{pH}$, and ease of purification make BglA from C. thermocellum a potential candidate in industrial applications.
\end{abstract}

\section{Introduction}

Cellulose is one of the polymers of glucose, having a headstrong lysis activity but is still renewable. This lytic reaction consists of endoglucanases and exoglucanases fundamental activities, by acting on cellulose, and produces cellobiose with cellooligosaccharides. At this stage, betaglucosidase converts cellobiose and cellooligosaccharides into glucose molecules. Glucose produced in this instance imparts end product inhibition through stearic hindrance to the glucanases. Alternatively, the processive endoglucanases had their own mechanism for converting cellulose into glucose, which is equivalent to endoglucanases and cellobiohydrolases. Thus, utilization or removal of excessive cellobiose from the system by the activity of beta-glucosidase evades the inhibition caused by cellobiose accumulation. Therefore, glucosidase is a part of well-characterized cellulolytic systems along with other cellulases $[1,2]$.

Clostridium thermocellum (C. thermocellum) is a cellulolytic thermophile, which uses a highly active enzymatic structure having a collection of exoglucanases and endoglucanases along with two beta-glucosidases, namely, BglA and BglB. Its cellulolytic activity is, however, affected by the accumulation of cellobiose, mainly due to inhibition of beta- 
glucosidases. This inhibition if somehow catered will not only enhance the extent of final glucose conversion from cellobiose but can also elevate the reaction rate [3].

Most industrial processes make use of higher temperatures, as they enhance the catalysis rate as well as hydrolytic efficiency. Table 1 shows a comparison of several tested betaglucosidases indigenously produced by different microorganisms at industrial scale by the fermentation process.

Thus, search of thermostable enzymes which can withstand higher temperatures are active nowadays. Several cellulosic components like xylanases and endoglucanases of $C$. thermocellum have proven to be competent enough with respect to their higher catalytic activity and thermostability, which implies that their glucosidase activity may also be loftier $[11,12]$. The present study was designed to clone and obtain soluble production of BglA from C. thermocellum in an Escherichia coli (E. coli) expression system with a better yield to be utilized in an industry at a cost-effective level. Furthermore, it was purified and characterized to attain its improved biological activity and thermostability.

\section{Materials and Methods}

2.1. Materials. In the current study, genomic DNA of $C$. thermocellum (ATCC ${ }^{\circledR} 27405 \mathrm{D}-5^{\mathrm{TM}}$ ) was procured from ATCC. The E. coli strains used for the propagation and expression of BglA were DH5 and BL21-CodonPlus (DE3)RIPL, respectively. For cloning and expression, different vectors were utilized, i.e., pTZ57R/T (Fermentas Inc., Ontario, Canada) and pET-28a (+) (Novagen, Madison, USA), respectively. NcoI and XhoI (Fermentas Inc., Ontario, Canada) restriction enzymes were used for restriction of cloning and expression vectors. However, InsTAclone ${ }^{\mathrm{TM}}$, TransformAid $^{\mathrm{TM}}$, DNA/plasmid extraction, and BigDye Terminator v3.1 Cycle Sequencing kits utilized in the present study were obtained from Thermo Scientific.

\subsection{T/A Cloning and Sequencing of BglA. The C. thermocellum} genomic DNA was used to amplify bglA gene-coding sequence by using a pair of primers with $5^{\prime}$ upstream restriction recognition sequences to integrate the restriction sites in an amplicon. The forward primer $5^{\prime}$ GCCCATGGCAAAGATAACTTTCC ${ }^{\prime}$ with NcoI (italicized) and reverse primer $5^{\prime} \mathrm{GCCTCGA-}$ GAAAACCGTTGTTTTTGATTA3' with XhoI (italicized) sites were used. The thermal cycling conditions were set as $5 \mathrm{~min}$ at $95^{\circ} \mathrm{C}, 30$ cycles of $45 \mathrm{sec}$ at $94^{\circ} \mathrm{C}, 45 \mathrm{sec}$ at $58^{\circ} \mathrm{C}$, and $1 \mathrm{~min}$ at $72^{\circ} \mathrm{C}$ with a final extension phase at $72^{\circ} \mathrm{C}$ for 20 minutes. The amplified bglA amplicon (1350 bp) was gel purified and ligated in a linear cloning vector, i.e., pTZ57R/T using InsTAclone ${ }^{\mathrm{TM}}$ kit and transformed into an E. coli strain, $\mathrm{DH} 5 \alpha$, via TransformAid ${ }^{\mathrm{TM}}$ kit according to the manufacturer's protocol.

The confirmed transformants were selectively propagated for sequence analysis of bglA gene from pTZ57R- $b g l A$ recombinant plasmid. The dideoxy chain termination method was used for sequencing using BigDye Terminator v3.1 Cycle Sequencing kit on the GA 3500 genetic analyzer (Applied Biosystems $^{\mathrm{TM}}$ ).
2.3. Construction of Expression Vector. For the construction of expression vector, the recombinant plasmid (pTZ57RbglA) was restriction digested with $\mathrm{NcoI} / \mathrm{XhoI}$ enzymes to obtain the insert for pET-28a (+) vector. Prior to ligation, the vector was also digested with the same enzymes. The ligated vector (pET28a-bglA) was twice transformed into $E$. coli strains; first in cloning strain $\mathrm{DH} 5 \alpha$, later the positive plasmid was retransformed into expression strain BL21 CodonPlus (DE3)-RIPL. The positive transformants were confirmed by colony PCR and restriction analysis.

The confirmed transformants of E. coli BL21 CodonPlus (DE3)-RIPL cells were processed for expression of BglA enzyme. $50 \mathrm{ml}$ Luria-Bertani (LB) medium supplemented with kanamycin $(100 \mu \mathrm{g} / \mathrm{ml})$ was used for culturing overnight at $37^{\circ} \mathrm{C}$ and $150 \mathrm{rpm}$. Next morning, $100 \mathrm{ml} \mathrm{LB}$ was supplemented with $2 \%$ overnight culture and allowed to grow up to an $\mathrm{OD}_{600}$ of 0.8 at $37^{\circ} \mathrm{C}$. At this point the cells were induced with $0.5 \mathrm{mM}$ IPTG, $\mathrm{OD}_{600}$ was measured every 2 hours and cells were harvested as they reached stationary phase. To confirm the expression of bglA gene as BglA enzyme, cells of $1 \mathrm{ml}$ culture were pelleted and resuspended in lysis buffer (1.5 M Tris-Cl, 0.5 mM PMSF). Cells were then lysed by sonication and centrifuged to separate the inclusion body and soluble fraction of the released proteins. Further protein analysis was done by SDS-PAGE $(12 \% \mathrm{v} / \mathrm{v})$.

2.4. Optimization of BglA Expression. The optimization of BglA was carried out using three media, namely, LB, Terrific broth (TB), and M9NG [13]. For each medium, culturing was initiated by refreshing an overnight culture in $50 \mathrm{ml}$ to $0.8 \mathrm{OD}_{600}$ and then induced. Each medium was investigated for a decline phase time span by inducing with either IPTG or lactose (autoinduction). After determining the time frame for each medium, different inducer concentrations were tested. Tested final concentrations for IPTG were 0.1, 0.3, 0.5, 0.7 , and $0.9 \mathrm{mM}$, while for lactose, $5,10,15,20$, and $25 \mathrm{mM}$ were used. SDS-PAGE (12\%) was performed for all optimization experiments as mentioned above. The gels were visualized using the Gel Doc XR System (Bio-Rad Laboratories, Hercules, CA, USA) and analyzed densitometrically for getting relative concentration or percentage (relative to quantified total cellular protein by Bradford assay) using Image Lab Software 6.0.1 (Bio-Rad Laboratories, Hercules, CA, USA).

\subsection{Characterization of BglA}

2.5.1. His-Tag Purification of BglA. Purification of BglA enzyme was performed on the soluble fraction obtained after the lysis of induced E. coli BL21-CodonPlus (DE3)-RIPL cells. First, the soluble fraction was heat-treated at $65^{\circ} \mathrm{C}$ to precipitate the heat-sensitive $E$. coli proteins. The sample was centrifuged at 7000 RPM for 15 minutes, and the supernatant was processed for His-tagged column chromatography using Ni-NTA resin (Thermo Scientific) according to the manufacturer's protocol. The purified protein was first quantified using Bradford's method and spectrophotometry 
TABLE 1: Comparison of several microorganisms producing beta-glucosidase (BglA) and their activity in (U) with optimum pH and temperature.

\begin{tabular}{lcccccc}
\hline Sr. No. & BglA-producing microorganism & Optimum temperature & Optimum $\mathrm{pH}$ & Enzyme substrate & Activity (U) & Reference \\
\hline 1 & Bacillus halodurans & 45 & 8.0 & Lactose & 95.0 & {$[4]$} \\
2 & Bacillus licheniformis & 60 & 7.0 & Glucose & 45.0 & {$[5]$} \\
3 & Penicillium oxalicum & 30 & 7.0 & Cellulose & 150.0 & {$[6]$} \\
4 & Penicillium piceum & 70 & 4.0 & Glucose & 1.8 & {$[7]$} \\
5 & Penicillium echinulatum & 50 & 4.8 & Cellulose & 1.5 & {$[8]$} \\
6 & Penicillium sp. & 60 & 6.0 & Cellulose & 289.0 & {$[9]$} \\
7 & Micrococcus antarcticus & 25 & 6.5 & Cellobiose & 0.058 & {$[10]$} \\
\hline
\end{tabular}

at $280 \mathrm{~nm}$. The quantified protein was then analyzed by SDSPAGE $(12 \% \mathrm{v} / \mathrm{v})$ for the approximate molecular weight.

2.5.2. Enzymatic Activity. To find out the enzymatic activity of the purified BglA (salicinase), salicin (Sigma) was used as a substrate. Activity assays were done in $1.5 \mathrm{M}$ Tris-Cl buffer ( $\mathrm{pH}$ 7.0) with a final enzyme concentration of $10 \mathrm{ng}$. A series of different substrate concentrations ranging from 2.5 to $20 \mathrm{mM}$ were incubated with enzyme at $50^{\circ} \mathrm{C}$ for 30 minutes in a total volume of $150 \mu \mathrm{l}$. The liberated reducing sugars were quantified by 3,5-dinitrosalicylic acid (DNS) reagent. The incubated enzyme substrate mixture $(150 \mu \mathrm{l})$ was mixed with $150 \mu \mathrm{l}$ of DNS and boiled for 10 minutes to produce color. Final absorbance was taken at $545 \mathrm{~nm}$ [14] on a PR4100 microplate reader (Bio-Rad).

The BglA enzymatic activity was determined through the regression method by using the glucose standard curve. Unit of the activity was $\mu \mathrm{mol} \cdot \mathrm{min}^{-1}$, which corresponds to one unit of enzyme (U). The Michaelis-Menten model of kinetics was applied on activity data to confirm graphical consistency prior to using it for the double-reciprocal Lineweaver-Burk plot. The plot gave $K_{\mathrm{m}}$ (Michaelis-Menten constant) and $V_{\max }$ (maximal reaction velocity) values for BglA.

2.5.3. Temperature, $p H$ Optima, and Stability. The optimum temperature for reaction was determined by incubating the separate reactions on a range of temperature $\left(30-75^{\circ} \mathrm{C}\right)$ for 30 minutes in $1.5 \mathrm{M}$ Tris- $\mathrm{Cl}$ buffer ( $\mathrm{pH}$ 7). Similarly, for an optimum $\mathrm{pH}$ value of $\mathrm{BglA}$ reaction, a range of different $\mathrm{pH}$ values ( $\mathrm{pH} 4-10)$ was used in separate reactions. Citratephosphate buffer $(0.15 \mathrm{M})$ was used for $\mathrm{pH} 4-8$, while $1.5 \mathrm{M}$ Tris-Cl buffer was used for $\mathrm{pH} \mathrm{8-10.} \mathrm{Highest} \mathrm{enzymatic}$ activity in $\mathrm{U} / \mathrm{mg}$ gave the optimum temperature and $\mathrm{pH}$ values for BglA.

The stability of the BglA against temperature was measured by incubating the enzyme for one hour at 25$75^{\circ} \mathrm{C}$. Temperature interval was kept at $5^{\circ} \mathrm{C}$. The stability against $\mathrm{pH}$ was determined by incubating the enzyme at ambient temperature for 30 minutes in $0.15 \mathrm{M}$ citratephosphate buffer of $\mathrm{pH} 4-8$ and $1.5 \mathrm{M}$ Tris-Cl buffer of $\mathrm{pH}$ $8-10$. The residual activities in $\mathrm{U} / \mathrm{mg}$ gave the temperature and $\mathrm{pH}$ stability cutoff values for BglA.

2.5.4. Circular Dichroism Analysis. Native structure of the recombinant BglA was confirmed by circular dichroism
(CD) spectroscopy. Data were collected on a Chirascan-Plus spectrophotometer (Applied Photophysics), furnished with Peltier thermal-controlled cuvette holder. Protein solution containing $125 \mu \mathrm{g} / \mathrm{ml}$ in $20 \mathrm{mM}$ Tris-Cl pH (8.0) was scanned over a wavelength range of $186-280 \mathrm{~nm}$ at $20^{\circ} \mathrm{C}$ in duplicate manner using quartz cuvette of path length $1 \mathrm{~mm}$ at a bandwidth of $1 \mathrm{~nm}$. Secondary structure content was estimated using $\mathrm{CD}$ spectrum deconvolution software (CDNN) [15].

\section{Results and Discussion}

3.1. Overexpression and Optimization of BglA in Different Media. The E. coli BL21-CodonPlus (DE3)-RIPL cells harboring pET28a-bglA vector (Figure 1) confirmed the expression of BglA protein after being induced with IPTG. Postexpression protein analysis by $12 \%$ SDS-PAGE showed that the enzyme was mainly expressed as a soluble active protein having an approximate molecular mass of $53 \mathrm{kDa}$ which coincides with the calculated mass (Figure 2).

To obtain the maximum expression of BglA in different media, a maximum cell density $\left(\mathrm{OD}_{600}\right)$ of 3.6 post 6 hours of induction with IPTG with an expression level of $~ 50 \%$ was achieved in LB, while autoinduction with lactose in LB medium gave a maximum cell density $\left(\mathrm{OD}_{600}\right)$ of 6.5 though maintaining an expression level of $\sim 50 \%$, whereas a maximum cell density of 5.5 and 16.4 in TB medium was achieved in 8 hours and 16 hours when induced with IPTG and lactose, respectively, with an expression level of $\sim 70 \%$. However, maximum cell density in autoinduction medium M9NG was 13.4 with an expression level of $~ 70 \%$. M9NG was also induced with IPTG with a maximum $\mathrm{OD}_{600}$ of 3.47 and an expression level of less than $\sim 40 \%$. A comparison of all these outcomes in three media is given in Table 2. BglA from C. thermocellum was first purified in 1979 [16] at $\sim 50 \mathrm{kDa}$ and was reported through DISK electrophoresis. Another study elucidated the coding sequence of bglA gene and predicted its size to be $\sim 51.5 \mathrm{kDa}$ [17]. The nucleotide sequence and size of cloned bglA in our study coincides with both of the prior studies. Several beta-glucosidases from other thermophilic bacteria have also been reported with similar sizes. Slight variations in size by different studies may be due to mass estimation by SDS-PAGE rather than by mass spectrometry $[1,4]$.

3.2. Solubility Analysis and Purification of BglA. After media optimization, M9NG (1 liter culture) was utilized for large 


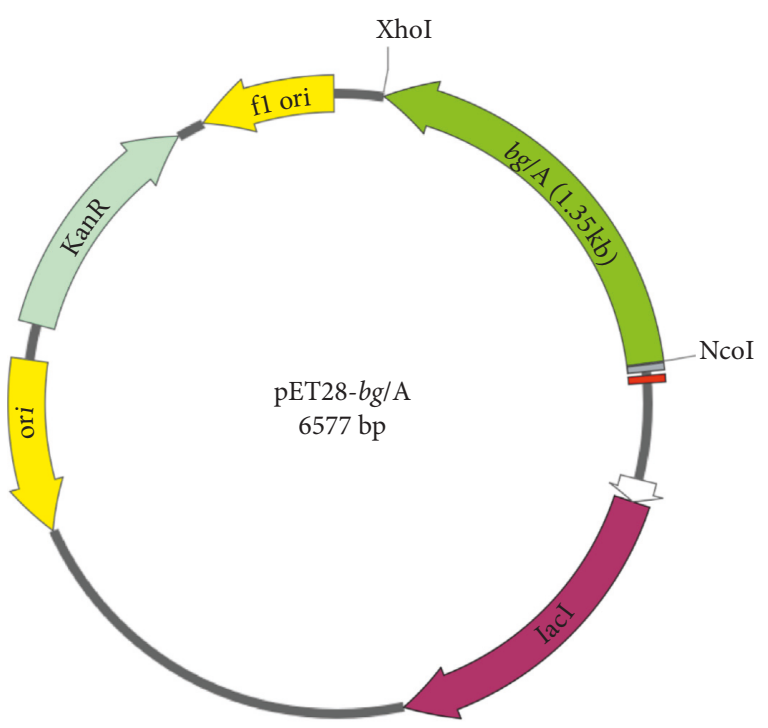

FIgURE 1: Graphical representation of pET28a-bglA. Expression vector was created by insertion of bglA gene between NcoI and XhoI sites. Inserted sequence was adjacent to lac operator and terminates at $6 \mathrm{xHis}$-tag included in the frame. $\operatorname{Kan}^{\mathrm{R}}$ : kanamycin resistance gene, Ori: origin of replication. The sketch was created using SnapGene ${ }^{\circledR}$ software (GSL Biotech).

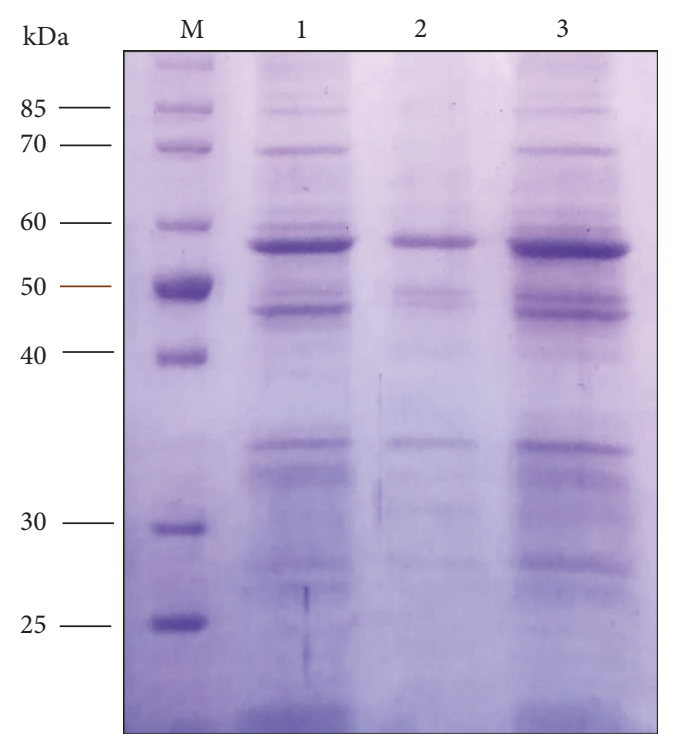

Figure 2: Expression analysis of BglA protein in E. coli BL21CodonPlus (DE3)-RIPL by $12 \%$ SDS-PAGE. Lane M: protein standard marker; Lane 1: soluble proteins showing expression of BglA at $\sim 53 \mathrm{kDa}$; Lane 2: insoluble proteins; Lane 3: total cellular proteins showing expression of BglA at $\sim 53 \mathrm{kDa}$.

scale production, and $100 \mathrm{ml}$ cell lysate yielded $~ 75 \%$ expression of BglA protein relative to the total cellular protein (TCP). The soluble fraction of the lysate contained $\sim 75 \%$ soluble BglA of the total expression while $\sim 25 \%$ remained as insoluble (Figure 2). Heat inactivation of the soluble fraction precipitated out $\sim 20 \%$ of the protein leaving $\sim 30 \%$ biologically active BglA. This 30\% was purified up to a purity level of $\sim 98 \%$ BglA by Ni-
TABLE 2: Summary of BglA optimization in different media (LB, $\mathrm{TB}$, and M9NG) with IPTG and lactose as inducers.

\begin{tabular}{lcccc}
\hline $\begin{array}{l}\text { Expression } \\
\text { inducer }\end{array}$ & $\begin{array}{c}\text { Growth } \\
\text { medium }\end{array}$ & $\begin{array}{c}\text { Max } \\
\mathrm{OD}_{600}\end{array}$ & $\begin{array}{c}\text { BglA \% in } \\
\text { TCP }\end{array}$ & $\begin{array}{c}\text { BglA mg/ } \\
\mathrm{ml}^{\mathbf{a}}\end{array}$ \\
\hline \multirow{3}{*}{ IPTG } & LB & 3.69 & 50 & 0.6 \\
& TB & 5.49 & 70 & 0.7 \\
& M9NG & 3.47 & 40 & 0.5 \\
Lactose & LB & 6.56 & 50 & 1.5 \\
& TB & 16.46 & 70 & 2.0 \\
& M9NG & 15.18 & 70 & 2.2 \\
\hline
\end{tabular}

Note. TCP: total cell protein. ${ }^{-}$Concentration determined through relative densitometry.

chromatography which resulted in a yield of $\sim 15 \%$ (Figure 3). Along with relative yield determination by densitometry after SDS-PAGE, protein content was also quantified at every purification step. The purified protein was quantified through Bradford assay which amounted to be $\sim 3.8 \mathrm{mg} / \mathrm{ml}$. A summary of BglA activity, percentage recovery, and fold purification is shown in Table 3. Several studies have reported soluble expression and purification of BglA from different bacterial linages of Thermotoga maritima (T. maritima) and Bacillus halodurans (B. halodurans) using the E. coli expression system in the range of $0.5-1 \mathrm{mg} / \mathrm{ml}$ ( $70 \%$ of TCP). These studies used LB and M9NG as growth media, while purification methods like ammonium sulfate precipitation and metal affinity chromatography were used $[4,18]$.

3.3. Enzymatic Activity and Stability of BglA at Different Temperature and $\mathrm{pH}$. BglA had a maximum activity of $11.8 \mathrm{kU} / \mathrm{mg}$ with salicin. The hydrolysis kinetics of salicin substrate by beta-glucosidase determined for 2.5 to $20 \mathrm{mM}$ concentration range are plotted (Figures $4(\mathrm{a})$ and $4(\mathrm{~b})$ ). The calculated values for $K_{\mathrm{m}}$ and $V_{\max }$ were $19.83 \mathrm{mM}$ and $0.12 \mu \mathrm{mol} \cdot \mathrm{min}^{-1}$, respectively, for salicin. The enzymatic activity of the BglA from native C. thermocellum has not been reported yet to our knowledge. BglA activities $\left(K_{\mathrm{m}}\right)$ in other bacterial lineages like $B$. halodurans and T. petrophila have been stated to be $4 \mathrm{mM}$ and $2.8 \mathrm{mM}$, respectively $[1,20]$.

BglA was analyzed for the optimum activity within a range of temperature, i.e., $30-75^{\circ} \mathrm{C}$, and the enzyme showed maximum activity at $50^{\circ} \mathrm{C}$ (Figure $5(\mathrm{a})$ ). The enzyme stayed active up till a temperature of $60^{\circ} \mathrm{C}$ after which there was a gradual decrease in its residual activity (Figure 5(b)).

Similarly, optimum activity within a range of $\mathrm{pH}(4-10)$ was analyzed for BglA, and it showed maximum activity at $\mathrm{pH} 7.0$ and was considered to be optimum (Figure 6(a)). Moreover, the stability against $\mathrm{pH}$ was also seen up to $\mathrm{pH}$ 7.0, after which there was a sharp decrease in the activity (Figure 6(b)). The temperature and $\mathrm{pH}$ optima were in accordance with thermophilic nature of BglA's source. The other beta-glucosidase (BglB) of C. thermocellum cloned [3] had an optimum temperature of $45^{\circ} \mathrm{C}$ and an optimum $\mathrm{pH}$ of 5.6 in contrast. However, in our case, BglA had a better stability, i.e., $60^{\circ} \mathrm{C}$ than $\mathrm{BglB}$ which was $45^{\circ} \mathrm{C}$. 


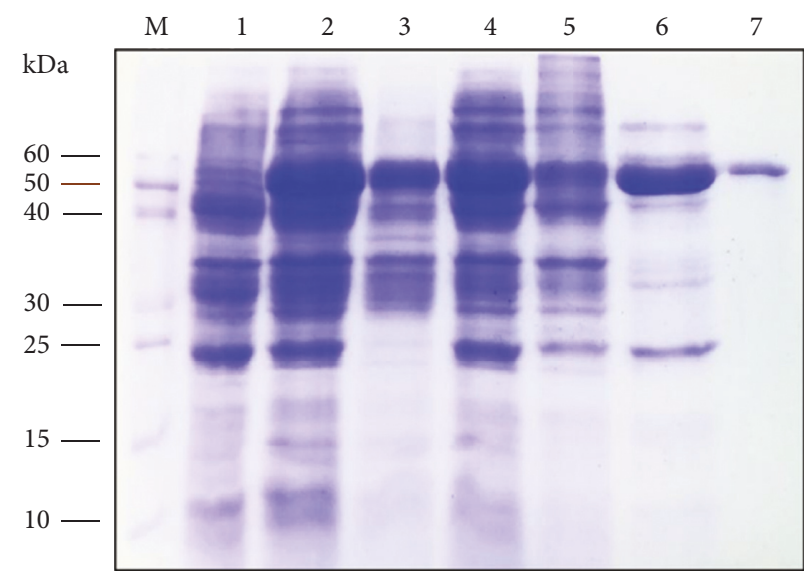

FIGURE 3: Solubility analysis and purification of BglA by 12\% SDS-PAGE. Lane M: protein standard marker; Lane 1: control (pET28a, without gene of interest); Lane 2: pET28a-bglA, total cellular protein (TCP) of E. coli BL21-CodonPlus (DE3)-RIPL cells showing expression of BglA at $\sim 53 \mathrm{kDa}$; Lane 3: insoluble fraction of TCP; Lane 4: soluble fraction of TCP showing expression of BglA at $\sim 53 \mathrm{kDa}$; Lane 5: pelleted proteins after heat inactivation of soluble fraction; Lane 6: supernatant proteins after heat inactivation of soluble fraction; Lane 7: purified His-tagged BglA protein through $\mathrm{Ni}^{2+}$-NTA chromatography.

TABLE 3: Summary of BglA recovery and activity at different stages of purification.

\begin{tabular}{|c|c|c|c|c|c|c|}
\hline Purification stages & $\begin{array}{l}\text { Total protein } \\
(\mathrm{mg} / \mathrm{ml})\end{array}$ & $\begin{array}{c}\text { Percentage } \\
\text { recovery }(\%)^{\mathrm{a}}\end{array}$ & $\begin{array}{c}\text { Percentage } \\
\text { recovery }(\%)^{\mathrm{b}}\end{array}$ & $\begin{array}{c}\text { Total activity } \\
(\mathrm{U})\end{array}$ & $\begin{array}{c}\text { Specific activity } \\
(\mathrm{U} / \mathrm{mg})\end{array}$ & $\begin{array}{c}\text { Fold } \\
\text { purification }\end{array}$ \\
\hline Crude cell extract & 29.85 & 100 & 100 & 18704 & 627 & 1 \\
\hline Soluble fraction & 17.84 & 60 & 70 & 14250 & 799 & 1.27 \\
\hline $\begin{array}{l}\text { Treatment of soluble fraction } \\
\text { at } 65^{\circ} \mathrm{C}\end{array}$ & 15.57 & 52 & 30 & 13601 & 874 & 1.39 \\
\hline Ni-chromatography & 3.8 & 13 & 15 & 11807 & 3107 & 4.96 \\
\hline
\end{tabular}

${ }^{\mathrm{a}}$ Percentage recovery (\%) determined by Bradford assay [19]. ${ }^{\mathrm{b}}$ Percentage recovery (\%) determined by densitometry after SDS-PAGE.

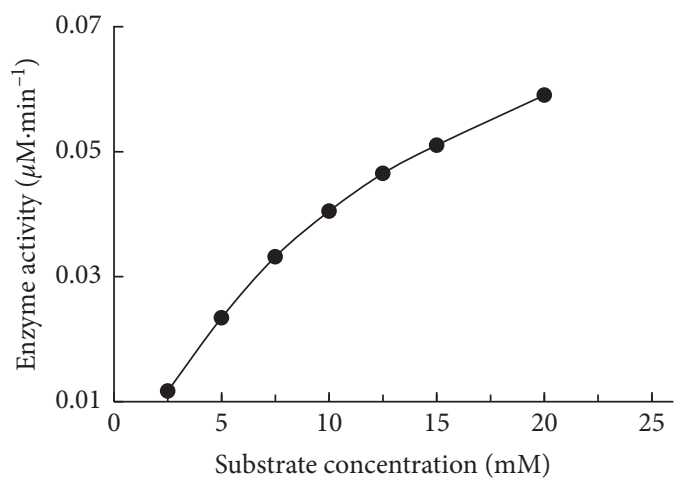

(a)

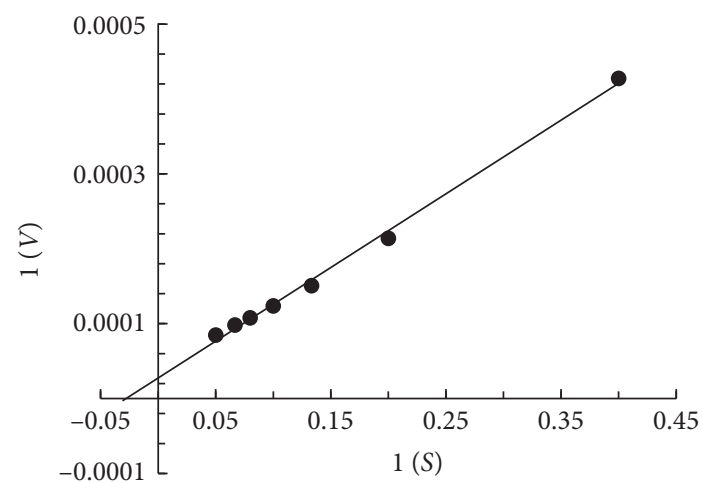

(b)

FIgURE 4: Enzymatic activity of BglA. (a) Lineweaver-Burk plot having substrate (salicin) concentration in mM on $X$-axis and enzyme (BglA) activity in $\mu \mathrm{M} \cdot \mathrm{min}^{-1}$ on $Y$-axis; (b) reciprocated substrate concentration and enzyme activity values from which Michaelis-Menten constant was derived through nonlinear regression.

3.4. Circular Dichroism Spectrum of BglA. CD spectrum of BglA is shown in Figure 7. A characteristic positive peak at $193 \mathrm{~nm}$ and a negative peak around $222 \mathrm{~nm}$ indicated a predominant $\alpha$-helical content [21], whereas a positive peak near $195 \mathrm{~nm}$ and a negative peak at $208 \mathrm{~nm}$ showed presence of $\beta$-pleated sheets [22].

The secondary structure determined by CD spectroscopy in our study (as shown in Table 4) is comparable with the secondary structure content obtained, from both $\mathrm{X}$-ray crystallography- (PDB ID: 5OGZ) and homology-based predicted models [23], along with in silico sequence-based prediction of secondary structure using Mufold [24]. The CD spectra revealed presence of alpha helix (43.50\%) and a small percentage of beta sheets $(10.60 \%)$.

In silico rendering of the $\mathrm{X}$-ray crystallographic model and homology-based predicted model was also constructed by using UCSF Chimera [25]. Visual elaboration of mainly present alpha helices and minor percentages of beta sheets 


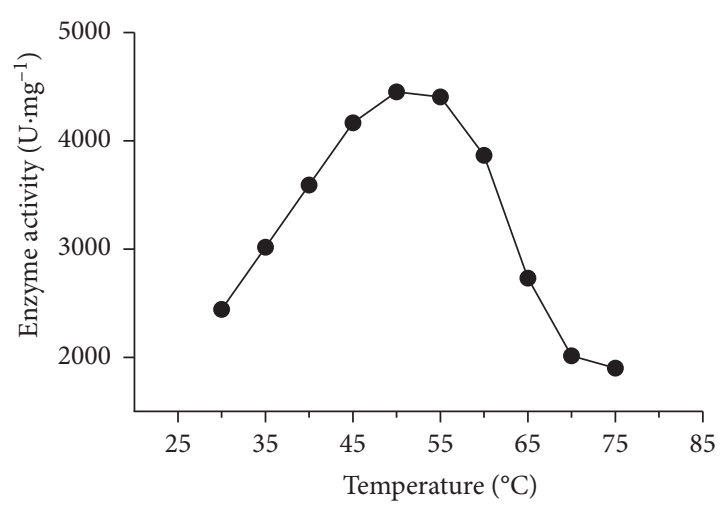

(a)

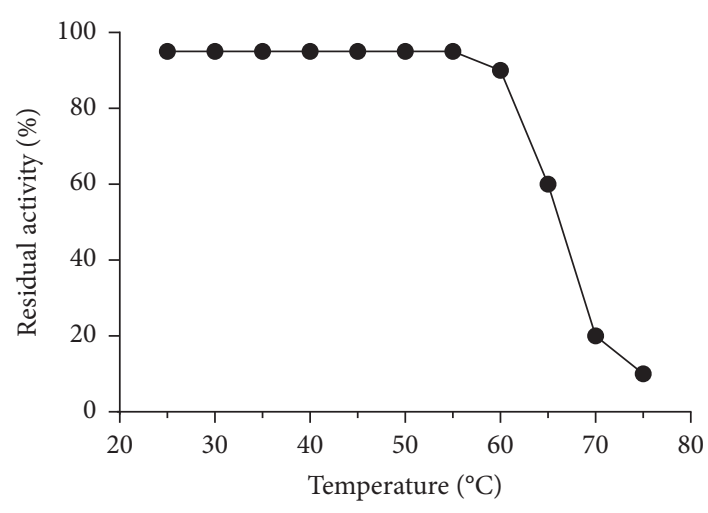

(b)

Figure 5: Optimum temperature characteristics and stability against temperature of BglA. (a) Enzyme activity of BglA (•) plotted against different temperatures $\left(30-75^{\circ} \mathrm{C}\right)$. Maximum activity can be noticed at an optimum temperature, i.e., $50^{\circ} \mathrm{C}$. (b) residual activity percentage of $\mathrm{BglA}(\bullet)$ is plotted after incubation at different temperatures irrelatively and a sharp decrease in activity can be seen after $60^{\circ} \mathrm{C}$.

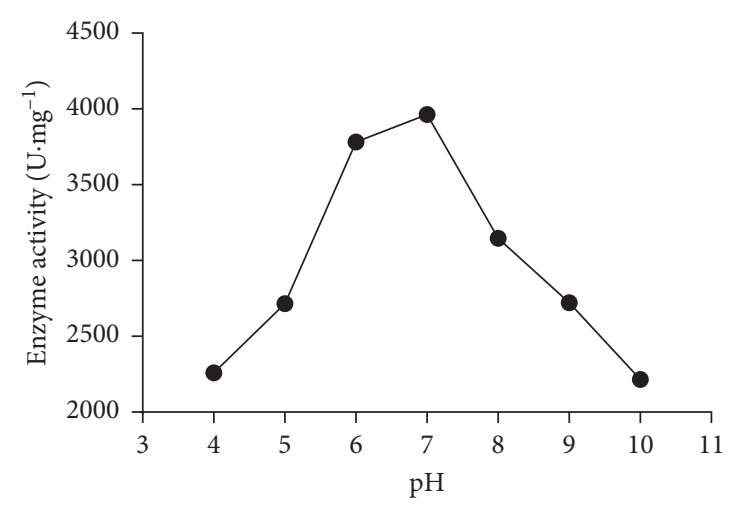

(a)

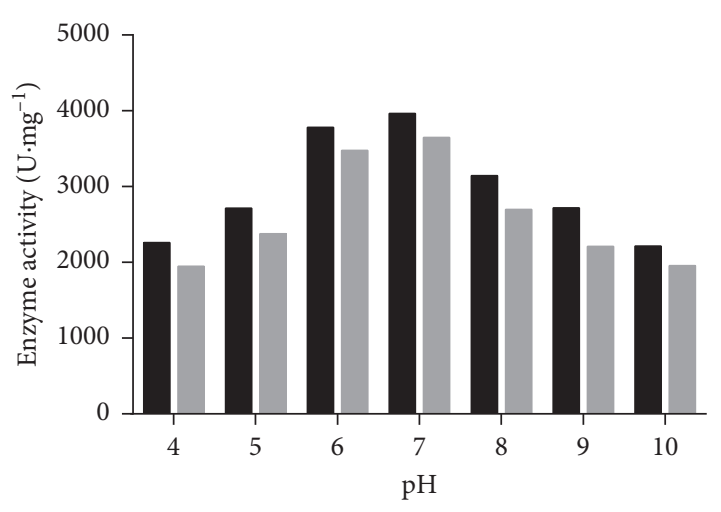

(b)

FIgURE 6: Optimum pH characteristics and stability against pH of BglA. (a) Enzyme activity of BglA (•) plotted against different pH (4-10). Maximum activity can be noticed at an optimum pH, i.e., 7.0; (b) residual activity comparison as bar graph of BglA showing actual activity (black bars) at different $\mathrm{pH}$ values and residual activity (Grey bars) plotted after incubation at different $\mathrm{pH}$ values irrelatively and an extent of decrease in the activity at each $\mathrm{pH}$ value can be seen.

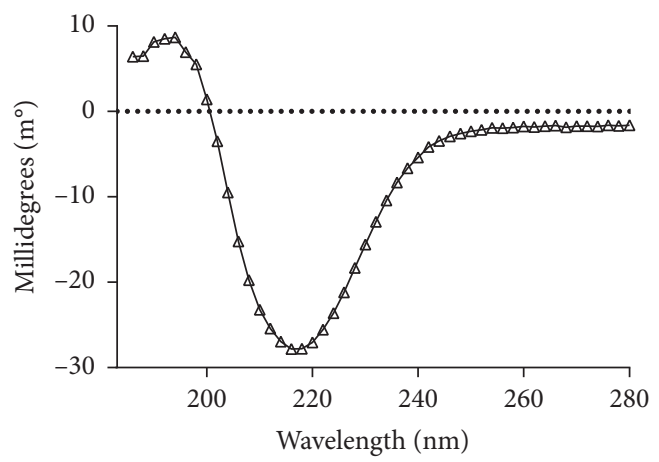

Figure 7: CD spectrum of BglA in $20 \mathrm{mM}$ Tris-buffer (pH 7.0). The CD spectrum was measured from 186 to $280 \mathrm{~nm}$ in a $1 \mathrm{~mm}$ pathlength quartz cell with a step size and bandwidth of $1 \mathrm{~nm}$ each. The concentration of BglA was $100 \mu \mathrm{g} / \mathrm{ml}$.

can be seen in Figure 8. Pairwise sequence alignment was done by using MatchMaker command of Chimera followed by superimposing the structures according to those pairwise alignments.

\section{Conclusions}

The lysis activity of cellulose includes a chain of reaction, starting from endoglucanases and then beta-glucosidase, 
TABLE 4: Secondary structure predictions of BglA by CD spectroscopy and comparison with other models.

\begin{tabular}{lcc}
\hline Models & Alpha helix (\%) & Beta sheets (\%) \\
\hline CD spectroscopy (BglA) & 43.50 & 10.60 \\
X-ray crystallography (PDB ID: 5OGZ) & 43.63 & 15.57 \\
Homology-based predicted model & 42.11 & 14.86 \\
Sequence-based prediction (Mufold) & 43.90 & 13.80 \\
\hline
\end{tabular}

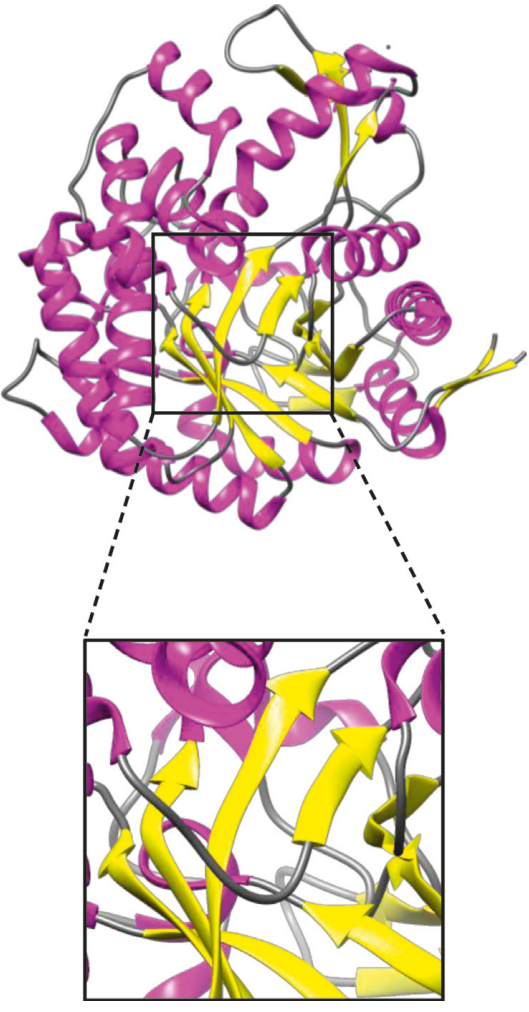

(a)

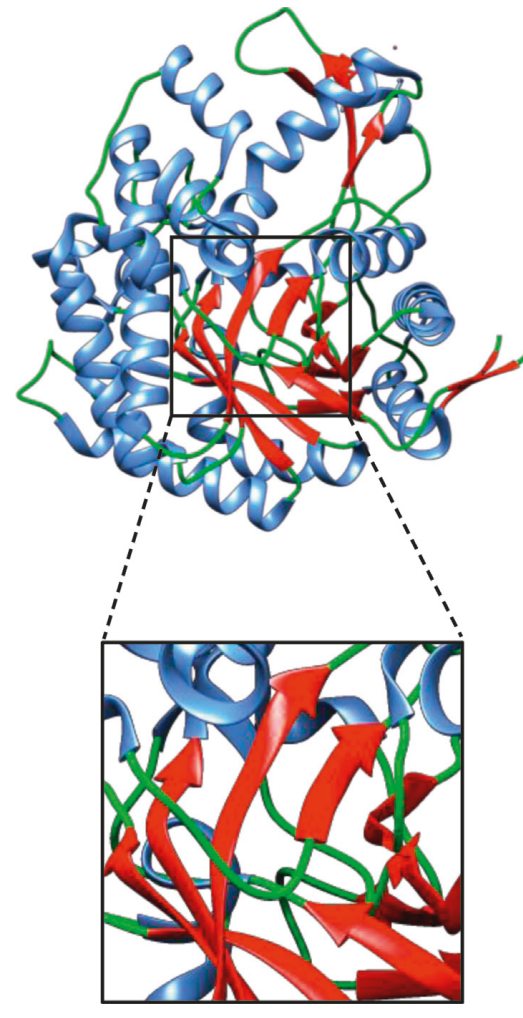

(b)

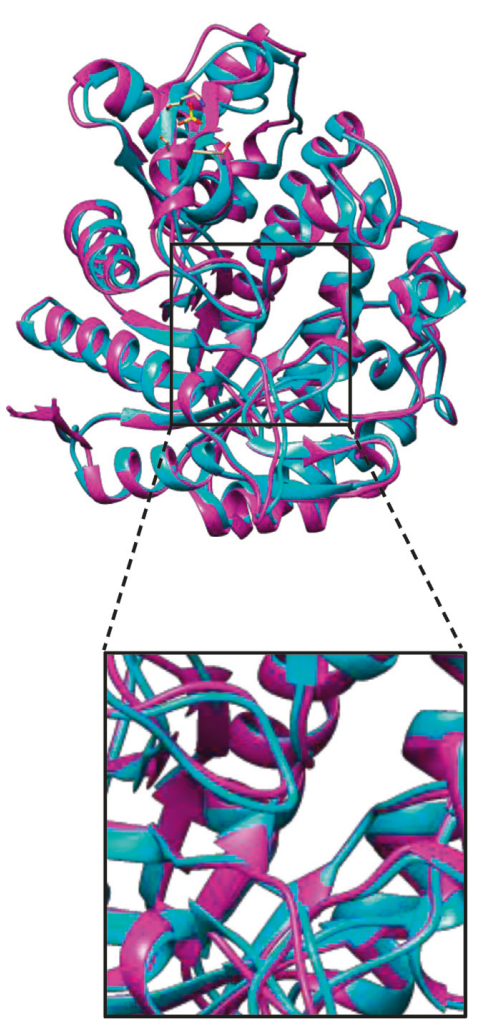

(c)

FIGURE 8: Tertiary structure model and comparison of BglA. (a) Modeled X-ray crystallographic structure of BglA (PDB ID: 5OGZ) showing alpha helices, beta sheets, and coils in magenta, yellow, and grey color, respectively; (b) homology-based predicted model of BglA showing alpha helices, beta sheets, and coils in cyan, red, and green color, respectively; (c) superimposed structure comparison of X-ray crystallographic and homology-based predicted models by using MatchMaker shown in magenta and cyan, respectively.

which ultimately converts cellooligosaccharides to glucose, but the product induces inhibition of prior enzymes. Our study aimed to clone and evaluate enzymatic activity and stability of BglA obtained from C. thermocellum in the E. coli expression system. The purified BglA showed soluble expression at $\sim 53 \mathrm{kDa}$ with promising enzymatic activity $(11.8 \mathrm{kU} / \mathrm{mg})$ with salicin. The enzymatic activity and stability analysis of BglA also showed its thermophilic capabilities well above average. In conclusion, purified BglA is a suitable candidate for industrial utilization due to its high-level expression in E. coli with better enzymatic activity and thermostability.

\section{Data Availability}

The data used to support the findings of this study are included within the article.

\section{Conflicts of Interest}

The authors declare no conflicts of interest.

\section{Authors' Contributions}

SSA participated in designing the study, carried out all the experiments, complied and interpreted the data, and drafted the manuscript. RG and MS managed the whole research project, supported in drafting, facilitated in providing all kinds of instrumental access and management and also helped in the final revision of the manuscript. MA coordinated the laboratory activity and assisted in the experiments. SK helped in final revision of the drafted manuscript. All the authors have read and approved the final version of the manuscript. 


\section{Acknowledgments}

The authors acknowledge the valuable administrative support by Late Dr. M. H. Qazi (Vice-Chancellor, The University of Lahore, Lahore, Pakistan).

\section{References}

[1] I. U. Haq, M. A. Khan, B. Muneer et al., "Cloning, characterization and molecular docking of a highly thermostable $\beta$-1,4-glucosidase from Thermotoga petrophila," Biotechnology Letters, vol. 34, no. 9, pp. 1703-1709, 2012.

[2] C. R. Waldron, C. A. Becker-Vallone, and D. E. Eveleigh, "Isolation and characterization of a cellulolytic actinomycete Microbispora bispora," Applied Microbiology and Biotechnology, vol. 24, no. 6, pp. 477-486, 1986.

[3] M. P. M. Romaniec, N. Huskisson, P. Barker, and A. L. Demain, "Purification and properties of the Clostridium thermocellum bglB gene product expressed in Escherichia coli," Enzyme and Microbial Technology, vol. 15, no. 5, pp. 393-400, 1993.

[4] S. Naz, N. Ikram, M. I. Rajoka, S. Sadaf, and M. W. Akhtar, "Enhanced production and characterization of a $\beta$-glucosidase from Bacillus halodurans expressed in Escherichia coli," Biochemistry, vol. 75, no. 4, pp. 513-518, 2010.

[5] G. Yao, R. Wu, Q. Kan et al., "Production of a high-efficiency cellulase complex via $\beta$-glucosidase engineering in Penicillium oxalicum," Biotechnology for Biofuels, vol. 9, no. 1, p. 78, 2016.

[6] J. A. Mendez-Liter, L. I. de Eugenio, A. Prieto, and M. J. Martínez, "The $\beta$-glucosidase secreted by Talaromyces amestolkiae under carbon starvation: a versatile catalyst for biofuel production from plant and algal biomass," Biotechnology for Biofuels, vol. 11, no. 1, p. 123, 2018.

[7] L. Gao, R. He, Z. Zong, and D. Zhang, "A $\beta$-glucosidase hyperproducing strain, Pencillium piceum: novel characterization of lignocellulolytic enzyme systems and its application in biomass bioconversion," in Fungal Cellulolytic Enzymes, pp. 81-106, Springer, Berlin, Germany, 2018.

[8] A. J. P. Dillon, M. Bettio, F. G. Pozzan, T. Andrighetti, and M. Camassola, "A new Penicillium echinulatum strain with faster cellulase secretion obtained using hydrogen peroxide mutagenesis and screening with 2-deoxyglucose," Journal of Applied Microbiology, vol. 111, no. 1, pp. 48-53, 2011.

[9] P. S. Santa-Rosa, A. L. Souza, R. A. Roque et al., "Production of thermostable $\beta$-glucosidase and CMCase by Penicillium sp. LMI01 isolated from the Amazon region," Electronic Journal of Biotechnology, vol. 31, pp. 84-92, 2018.

[10] H.-X. Fan, L.-L. Miao, Y. Liu, H.-C. Liu, and Z.-P. Liu, "Gene cloning and characterization of a cold-adapted $\beta$-glucosidase belonging to glycosyl hydrolase family 1 from a psychrotolerant bacterium Micrococcus antarcticus," Enzyme and Microbial Technology, vol. 49, no. 1, pp. 94-99, 2011.

[11] M. Sajjad, M. I. M. Khan, N. S. Akbar, S. Ahmad, I. Ali, and M. W. Akhtar, "Enhanced expression and activity yields of Clostridium thermocellum xylanases without non-catalytic domains," Journal of Biotechnology, vol. 145, no. 1, pp. 38-42, 2010.

[12] M. Sajjad, M. I. M. Khan, R. Zafar, S. Ahmad, U. H. K. Niazi, and M. W. Akhtar, "Influence of positioning of carbohydrate binding module on the activity of endoglucanase CelA of Clostridium thermocellum," Journal of Biotechnology, vol. 161, no. 3, pp. 206-212, 2012.

[13] S. Sadaf, M. A. Khan, and M. W. Akhtar, "Production of bubaline somatotropin by auto-induction in Escherichia coli,"
Biotechnology and Applied Biochemistry, vol. 47, no. 1, pp. 21-26, 2007.

[14] G. L. Miller, "Use of dinitrosalicylic acid reagent for determination of reducing sugar," Analytical Chemistry, vol. 31, no. 3, pp. 426-428, 1959.

[15] G. Böhm, R. Muhr, and R. Jaenicke, "Quantitative analysis of protein far UV circular dichroism spectra by neural networks," Protein Engineering, Design and Selection, vol. 5, no. 3, pp. 191-195, 1992.

[16] N. Aït, N. Creuzet, and J. Cattanéo, "Characterization and purification of thermostable $\beta$-glucosidase from Clostridium thermocellum," Biochemical and Biophysical Research Communications, vol. 90, no. 2, pp. 537-546, 1979.

[17] F. Grabnitz, M. Seiss, K. P. Rucknagel, and W. L. Staudenbauer, "Structure of the beta-glucosidase gene bglA of Clostridium thermocellum. Sequence analysis reveals a superfamily of cellulases and beta-glycosidases including human lactase/phlorizin hydrolase," European Journal of Biochemistry, vol. 200, no. 2, pp. 301-309, 1991.

[18] Y. Xue, X. Song, and J. Yu, "Overexpression of $\beta$-glucosidase from Thermotoga maritima for the production of highly purified aglycone isoflavones from soy flour," World Journal of Microbiology and Biotechnology, vol. 25, no. 12, pp. 21652172, 2009.

[19] M. Bradford, "A rapid and sensitive method for the quantitation of microgram quantities of protein utilizing the principle of protein-dye binding," Analytical Biochemistry, vol. 72, no. 1-2, pp. 248-254, 1976.

[20] Y. M. Xue, C. Y. Xu, J. J. Hou, X. Q. Li, and Z. G. Cao, "Enhanced soluble expression of a thermostble $\beta$-glucosidase from Thermotoga maritima in Escherichia coli and its applicaton in immobilization," Applied Biochemistry and Microbiology, vol. 51, no. 3, pp. 306-315, 2015.

[21] G. Holzwarth and P. Doty, "The ultraviolet circular dichroism of polypeptides1," Journal of the American Chemical Society, vol. 87, no. 2, pp. 218-228, 1965.

[22] N. J. Greenfield and G. D. Fasman, "Computed circular dichroism spectra for the evaluation of protein conformation," Biochemistry, vol. 8, no. 10, pp. 4108-4116, 1969.

[23] W. Kabsch and C. Sander, "Dictionary of protein secondary structure: pattern recognition of hydrogen-bonded and geometrical features," Biopolymers, vol. 22, no. 12, pp. 2577-2637, 1983.

[24] C. Fang, Y. Shang, and D. Xu, "MUFOLD-SS: new deep inception-inside-inception networks for protein secondary structure prediction," Proteins: Structure, Function, and Bioinformatics, vol. 86, no. 5, pp. 592-598, 2018.

[25] E. F. Pettersen, T. D. Goddard, C. C. Huang et al., "UCSF Chimera? A visualization system for exploratory research and analysis," Journal of Computational Chemistry, vol. 25, no. 13, pp. 1605-1612, 2004. 


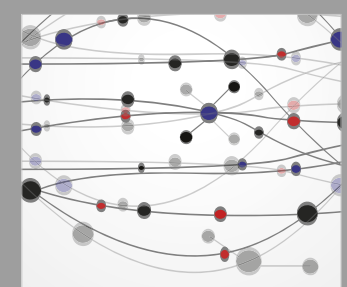

The Scientific World Journal
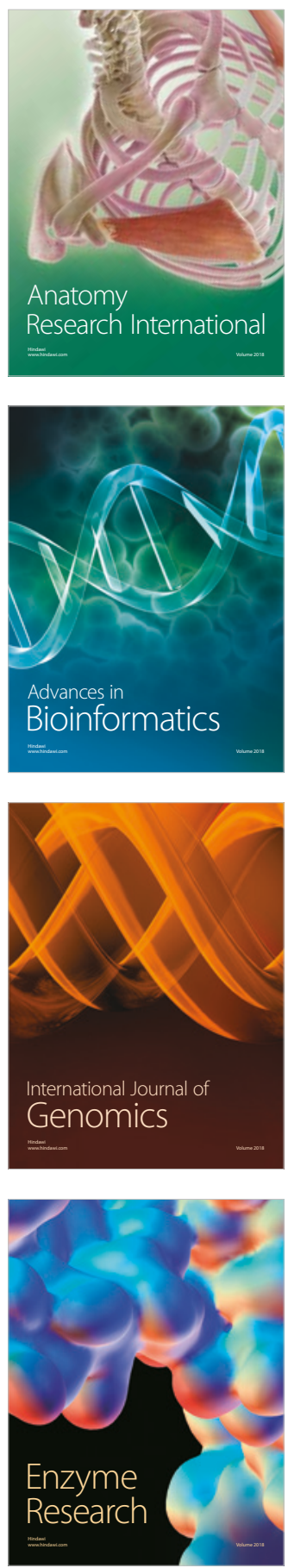
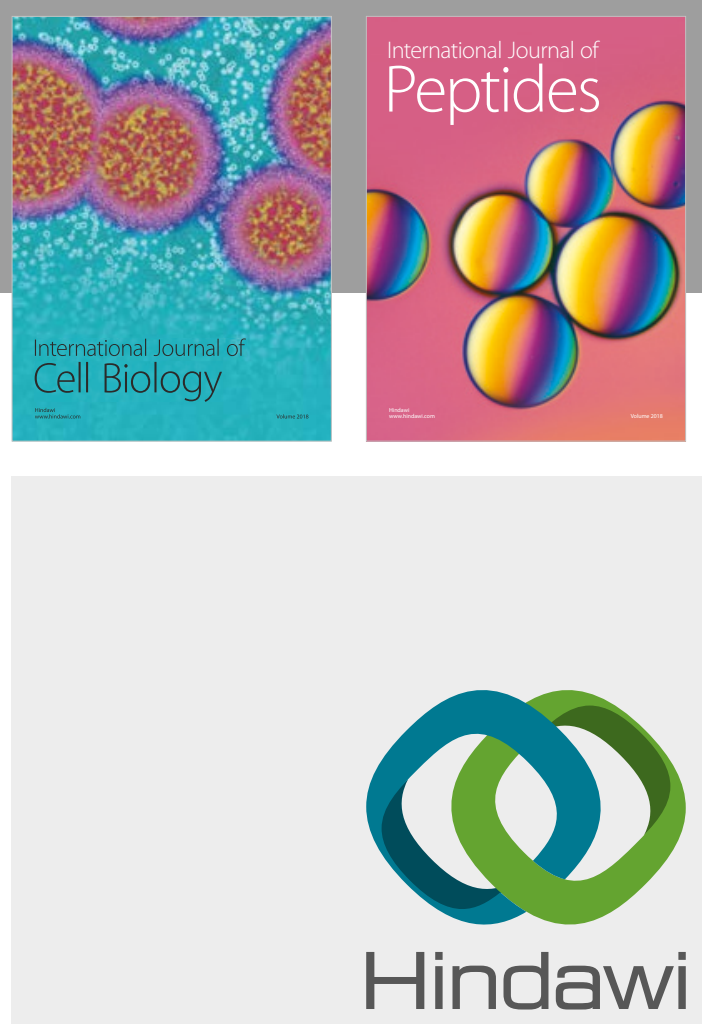

Submit your manuscripts at

www.hindawi.com
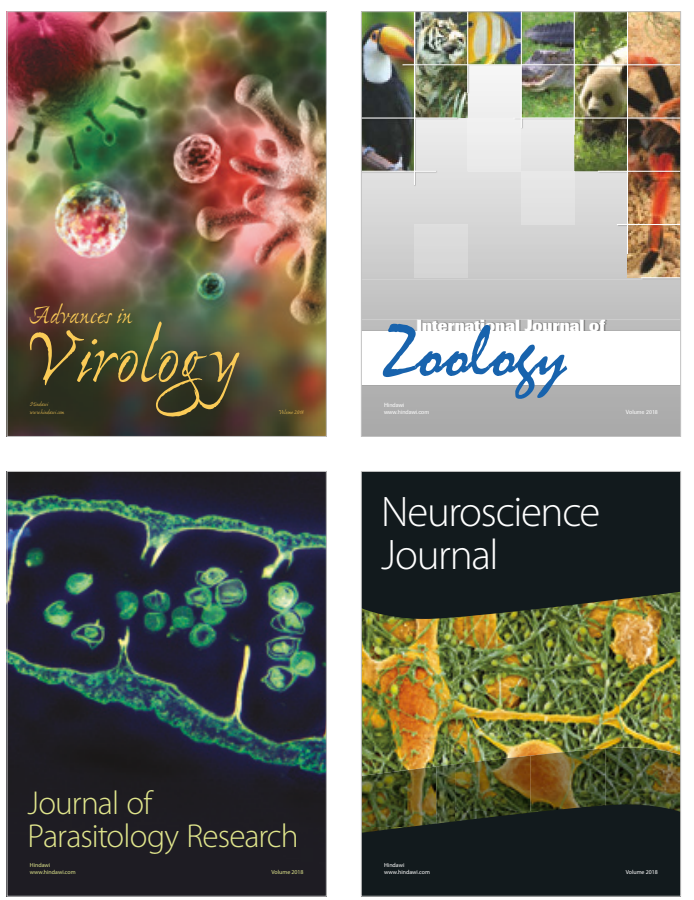
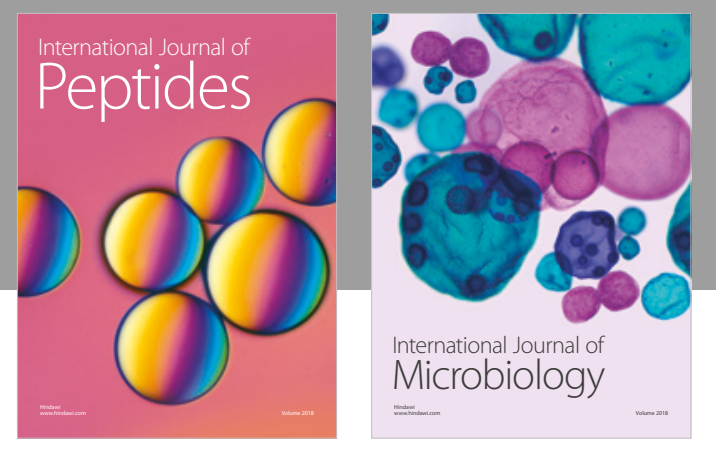

nternational Journal of Microbiology
Journal of
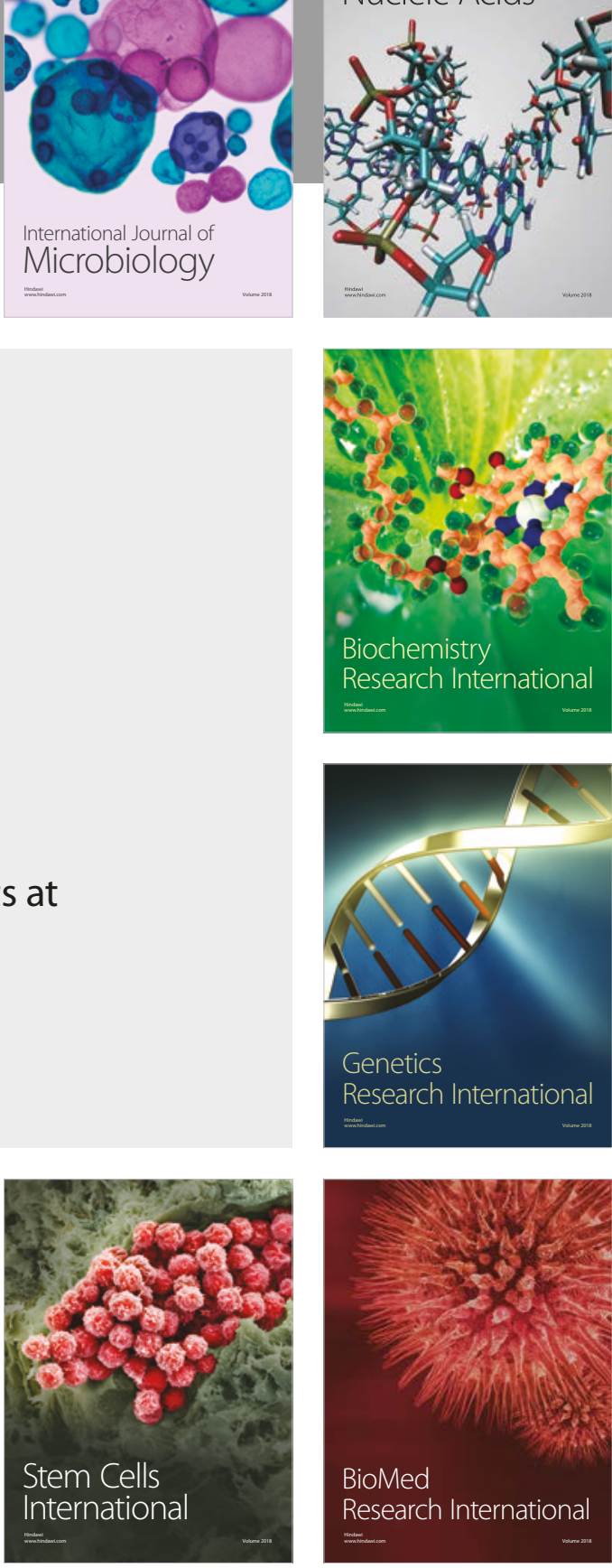
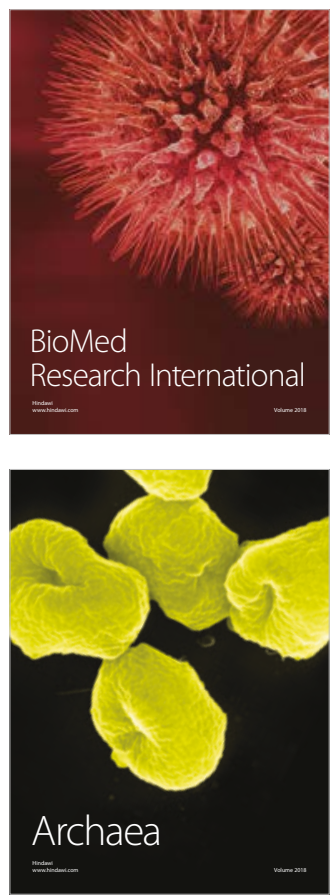